\title{
Pemberdayaan Pemerintah Desa Di Kecamatan Lantari Jaya Kabupaten Bombana
}

\author{
Tompo ${ }^{1}$ \\ ${ }^{1}$ Universitas Muslim Indonesia Makassar \\ Tallo, Kota Makassar
}

\begin{abstract}
,
Rural development plays an important role in the context of national development. Besides of it covers most of the territory of the Unitary State of the Republic of Indonesia, also about seventy percent of Indonesia's population living in rural areas. For that reason, Rural Community Development requires continuous efforts, because it has important role in strengthening national endurance. If it's measured by economic and social indicators, in general most of the existing Village welfare level is still relatively low. As can be seen in rural areas until now, where there are still many development imbalances between rural and urban. And the most important role to activate the wheels of development in rural areas is the village government through empowerment and society participation.
\end{abstract}

Keywords: Empowerment, Village Government, Social Welfare.

\section{PENDAHULUAN}

Desa merupakan struktur dan entitas terkecil yang terdapat dalam suatu negara, bagian terkecil ini tentunya berhubungan dan berkesinambungan dengan ketahanan nasional Negara Republik Indonesia (Hanif Nurcholis, 2011: 3). Desa pada umumnya dianggap oleh masyarakat di Indonesia adalah pedesaan yang mengalami perkembangan yang lamban. Keterbatasan kapasitas dan sumberdaya menyebabkan badai kemiskinan dan keterbelakangan dalam berbagai aspek kehidupan menjadi faktor stagnasi dalam menjalankan roda pembangunan nasional.

Pembangunan desa memiliki peran yang sangat penting dalam memperkuat ketahanan nasional melalui peningkatan perekonomian dan kesejahteraan masyarakat. Namun dalam realitasnya sampai sekarang ini kita masih dihadapkan pada berbagai ketimpangan pembangunan antara pedesaan dibandingkan dengan daerah perkotaan. Menurut Umbu Pariangu (2014; 46), jumlah desa di Indonesia tercatat 74 Ribu desa namun sebanyak 32 ribu desa masuk kategori tertinggal. Dari 32 Ribu desa tertinggal tersebut berisikan 57.5 Juta penduduk. Sebagian besar desa tertinggal tersebut berada di Indonesia bahagian Timur dan Sumatera. 
Dalam upaya mengatasi berbagai ketimpangan pembangunan antara pedesaan itu ialah melalui pembangunan masyarakat. Dan yang paling berperan untuk menggerakkan roda pembangunan itu adalah pemerintah desa, terutama dalam upaya menciptakan iklim yang mendorong tumbuhnya kesadaran partisipatif untuk berprakarsa dan berswadaya bagi masyarakatnya dalam setiap proses pembangunan, mulai pada saat penyusunan program, pelaksanaan, sampai pada tahap evaluasi.

Dalam pandangan Rahadjo Adisasmita (2007: 4), kesadaran masyarakat diperlukan bagi penguatan potensi sumberdaya manusia, sehingga memiliki kemampuan untuk memanfaatkan sumberdaya alam sekitarnya, yang selanjutnya akan mampu menciptakan keterkaitan fungsional sektor-sektor pembangunan antar desa, antar daerah pedesaan dan dengan daerah perkotaan dalam rangka memperkuat pembangunan nasional secara menyeluruh. Hal ini menuntut profesionalitas pemerintah desa dalam menjalankan tugas dan kewajibannya sesuai amanat Undang-Undang Nomor 6 Tahun 2014 tentang Desa.

Upaya untuk mewujudkan pemerintah desa yang professional dan responsif terhadap tuntutan kebutuhan dan kepentingan masyarakat memerlukan adanya pemberdayaan (empowering) pemerintah desa dengan asumsi bahwa apabila pemerintah desa berdaya, maka mereka mempunyai kemampuan untuk memenuhi kebutuhan sendiri secara mandiri. Selanjutnya mereka dapat membentuk pemerintah desa yang mandiri, tidak tergantung dari pihak luar (Azam Awang, 2010: 8).

Pemerintah desa secara historis dibentuk oleh masyarakat desa dengan memilih beberapa orang masyarakat yang dipercaya dapat mengatur, menata, melayani, memelihara, mempertahankan dan melindungi berbagai aspek kehidupan mereka. Aspek kehidupan masyarakat yang utama adalah hukum adat (istiadat) tertulis maupun tidak tertulis, social budaya kemasyarakatan, ekonomi pertanian-perkebunan-perikanan, perdagangan, ketertiban, keamanan dan pertahanan diri serta pemerintahan. Penerintah desa merupakan bentuk formalisasi kelembagaan masyarakat desa. Kehadiran pemerintah desa merupakan pemenuhan dan eksistensi masyarakat desa.

Dalam kepemimpinan tradisional masyarakat Tolaki (Pemerintah desa atau Tonomotuo) di Sulawesi Tenggara, menurut pandangan Abdurrauf Tarimana (1993: 189) terdapat tiga ide dasar, antara lain: (1) Petono'a (kemanusiaan), yakni kemanusiaan menurut 
Volume 01 Nomor 02 Ed. Desember 2019 : page ......

P-ISSN: 2686-262X E-ISSN : 2685-9300

DOI : $\mathrm{xxxxxx}$

ajaran dari pesan-pesan leluhur (pe'oliwi ari ine imbue); (2) Ponano ana niawo, to no nggapa, rome-romeno wonua (kehendak orang banyak); dan (3) Medulu, mepoko'aso (kesatuan dan persatuan). Adapun tujuan penyelenggaraan pemerintahan desa adalah mewujudkan masyarakat yang bersatu, makmur dan sejahtera.

Apabila dicermati tentang ide dasar dan tujuan penyelenggaraan pemerintahan tradisional masyarakat Tolaki di Sulawesi Tenggara, maka dapat dikonstatasikan bahwa hal tersebut sejalan dengan politik hukum pemerintahan desa sebagaimana diatur dalam UndangUndang Nomor 6 Tahun 2014 tentang Desa. Sehimgga dapat terjalin harmonisasi antara sistem pemerintahan tradisional yang bersendikan adat-istiadat dengan sistem pemerintahan nasional yang menjunjung kebhinekaan di Negara Republik ini.

Dalam rangka pemberdayaan pemerintah desa sebagai wujud dari penerapan semangat otonomi desa, maka pemerintah desa secara berjenjang sesuai dengan hirarkinya melimpahkan sebagian kewenangannya kepeda pemerintah desa. Pada dasarnya kewenangan dapat diartikan sebagai hak atau kekuasaan yang sah untuk bertindak atau melakukan sesuatu. Taliziduhu Ndraha (2003: 85) menyebutkan wewenang atau kewenangan adalah padanan kata "authority" yaitu the power or right delegated or given; the power to judge, act or command". Wewenang adalah kekuasaan yang sah. Sedangkan Max Weber dalam Taliziduhu Ndraha (2003: 8) berpendapat bahwa ada tiga macam tipe wewenang, yaitu: (1) Wewenang tradisional; (2) Wewenang kharismatik; (3) Wewenang legal-rasional. Dan wewenang yang ketiga menjadi basis wewenang pemerintahan.

Kebutuhan kewenangan pemerintah desa tidak lain adalah untuk memperbesar kewenangan mengatur dan mengurus rumah tangga sendiri serta untuk memperkecil intervensi pemerintah di atasnya dalam urusan rumah tangga sendiri. Dengan demikian, penyelenggaraan pemerintah desa merupakan kewewnangan desa itu sendiri, baik untuk membuat atau menetapkan suatu kebijakan itu sendiri yang didasarkan pada kebutuhan, kepentingan, dan aspirasi masyarakat lokal setempat sepanjang tidak bertentangan dengan peraturan PerundangUndangan yang ada.

Dalam upaya memberdayakan Pemerintah Desa di Kecamatan Lantari Jaya, Pemerintah Kbupaten Bombana membuat berbagai kebijakan antara lain: Peraturan Daerah Kbupaten Bombana Nomor 15 Tahun 2011 tentang Rencana Pembangunan Jangka Menengah 
Daerah Kabupaten Bombana Tahun 2011 - 2016, dan Peraturan Bupati Bombana Nomor 1 Tahun 2014 tentang Pedoman Pelaksanaan Gerakan Membangun Bombana dengan Ridha Allah (Gembira) Desa di Kabupaten Bombana. Namun hingga sekarang berdasarkan fenomena yang berkembang dan terlihat di lapangan, masih banyak desa yang kondisinya tidak jauh berubah seperti masa sebelumnya, terutama dilihat dari aspek sosial - ekonomi masyarakat.

Berdasarkan uraian permasalahan di atas, penulis mengkaji beberapa permasalahan politik hukum yang menjadi dasar pertanyaan dalam penelitian, sebagai berikut:

1. Bagaimana implementasi politik hukum pemberdayaan pemerintah desa untuk pembangunan masyarakat di Kecamatan Lantari Jaya?

2. Faktor-faktor apakah yang berpengaruh terhadap implementasi pemberdayaan pemerintah desa di Kecamatan Lantari Jaya?

Pertanyaan pertanyaan di atas memerlukan jawaban dalam merespon berbagai permasalahan terutama dalam konteks pembangunan masyarakat pedesaan melalui pendekatan berbagai konsep atau teori-teori yang solusif

\section{METODE PENELITIAN}

Dalam penelitian ini yang menjadi objek adalah pemerintah desa Lantari Jaya Kabupaten Bombana, dilihat dari optik politik-politik hukum pemberdayaan pemerintah desa, dengan menggunakan metode penelitian empiric dan normative dengan pertimbangan akan menganalisis peraturan perundang undangan yang berkenaan dengan norma hukum yang berkembang dalam implementasi kebijakan politik hukum pemberdayaan pemerintah desa dalam meningkatkan kinerja pembangunan masyarakat di Kecamatan Lantari Jaya Kabupaten Bombana.

Populasi dalam penelitian ini terdiri dari seluruh lapisan masyarakat yang berdomisili di 9 (Sembilan) desa yang ada di Kecamatan lantari Jaya Kabupaten Bombana, jumlah populasi yang begitu banyak dan sumber data yang luas, maka penentuan sampel di lakukan secara purposive sampling, yaitu dari 9 (Sembilan) desa yang ada, yang di ambil hanya 5 (lima) desa sebagai sampel, yaitu: Desa Lantari, Desa Anugrah, Desa Lomba kasih, Desa Rarongkeu, dan Desa Watu-Watu. Di tiap-tiap desa di tentukan 10 (sepuluh) responden, sehingga jumlah responden keseluruhan adalah sebanyak 50 (lima puluh) orang yang terdiri dari unsur pemerintah desa, badan permusyawaratan Desa (BPD) dan tokoh-tokoh masyarakat/Agama. 
Adapun jenis data yang di gunakan dalam penelitian ini terdiri atas:

a. Data Primer atau data empiris yaitu data yang di peroleh dari hasil penelitian langsung di lokasi penelitian yang telah di tentukan. Perolehan data yang di maksud, bersumber dari hasil dialog interaktif (wawancara, interview, tanyajawab) dan sekaligus melakukan pengedaran daftar pertanyaan (quesioner) kepada responden, serta melakukan pengamatan 9observasi)

b. Data Sekunder atau data normative yaitu data yang di peroleh dari hasil penelitian, penelusuran, perpustakaan. Perolehan data yang di maksud bersumber dari buku litratur, laporan kajian ilmiah, majalah atau koran dan peraturan perundang-undangan.

Keseluruhan data yang di peroleh dalam penelitian ini, di olah dengan menggunakan dua macam analisis, yaitu analisis kualitatif dan analisis kuantitatif yang ada hubungannya dengan penelitian ini yang berjudul "Politik Hukum Pemberdayaan Pemerintah Desa Di Kecamatan Lantari Jaya Kabupaten Bombana". Sedangkan analisis data yang di kuantifikasikan berdasarkan jawaban responden digunakan rumus sebagai berikut:

$$
\begin{aligned}
& \mathrm{P}=\frac{F}{N} \mathrm{X} 100 \\
& \text { Keterangan : } \mathrm{P}: \text { Persentase } \\
& \mathrm{F}: \text { Frekwensi jawaban koresponden } \\
& \mathrm{N}: \text { Sampel }
\end{aligned}
$$

100 : Angka pembulat

\section{HASIL DAN PEMBAHASAN}

Penggunaan istilah “Desa”_di Sulawesi Tenggara di mulai sekitar tahun 1961, sejak berlakunya Undang-undang Nomor 13 tahun 1961 tentang Ketentuan-Ketentuan Pokok Kepolisian Negara. Sebelumnya istilah yang dipakai oleh orang Tolaki untuk pengertian Desa adalah $\boldsymbol{O}$ Napo_(Lembah, daratan) yang di kepalai oleh seorang yang bergelar “Tonomotua" (ketua, orang yang dituakan). Gabungan dari empat sampai tujuh “O Napo” merupakan O Tobu (wilayah) yang di kepalai oleh seorang "Putobu" (kepala wilayah, kepala distrik, camat). Istilah umum untuk tiap wilayah tempat tinggal adalah Wanua atau Negeri, atau O Lipu, yang berarti liputan atau wilayah (Abdurrauf Tarimana, 1993: 195-197).

Dalam komunitas orang moronene di Kabupaten Bombana istilah "Desa" sebelum berlakunya undang-undang nomor 13 tahun 1961 adalah “Limbo” yang di kepalai oleh seorang raja dengan gelar Mokole. Limbo adalah gabungan dari beberapa "Tobu" (Kampung) yang di kepalai oleh seorang "Putobu" (orang yang di tuakan). "Putobu" mempunyai beberapa 
perangkat di bawahnya yang memiliki tugas dan tanggung jawab masing-masing untuk menjalankan roda pemerintahan.

Kepemimpinan tradisional masyarakat moronene, Mokole (Raja) mempunyai kewenangan dan tanggung jawab yang luas dalam mengatur dan mengurus urusan rumah tangga daerahnya. Mokole benar-benar di berdayakan dalam menjalankan tugas dan funsinya sebagai pemimpin di daerahnya. Hubungan emosional antara Mokole dan warganya sangat kuat, kepatuhan dan kesetiaan kepada Mokole sangat tinggi sehingga terjalin harmonisasi dan interaksi dalam merumuskan kebijakan dan memecahkan berbagai persoalan yang di hadapi

Seiring dengan perkembangan dinamika kehidupan yang dihadapi masyarakat, politik hukum pemberdayaan pemerintah desa telah diatur dalam berbagai regulasi sejak berdirinya Negara Republik Indonesia Tanggal 17 Agustus 1945 sampai sekarang. Namun tidak sepenuhnya memenuhi kebutuhan dan kepentingan masyarakat. Oleh Karena itu, perlu dilakukan pengkajian lebih lanjut terhadap efektifitas implementasi politik hukum pemberdayaan pemerintah desa untuk mewujudkan tujuan kehidupan berbangsa dan bernegara.

Berdasarkan hasil penelitian, terdapat beberapa faktor yang mempengaruhi terhadap implementasi politik hukum pemberdayaan pemerintah desa di Kecamatan Lantari jaya, kabupaten Bombana antara lain:

\section{Faktor Sumberdaya Manusia}

Manusia adalah pelaku utama pembangunan dan sekaligus menjadi tujuan pembangunan. Hal ini berarti keberhasilan dan kegagalan pembangunan masyarakat ditentukan oleh manusianya dan keberhasilan suatu pembangunan dapat diukur dari tingkat kesejahteraan masyarakat.

Dalam konteks pemberdayaan pemerintah desa, tidak dapat dipisahkan dari aspek sumberdaya pemerintah desa sebagai penggerak utama (prime mover) pembangunan masyarakat. Implikasinya adalah keberhasilan kepemimpinan pemerintah desa dalam menjalankan tugas dan kewajibannya sangat ditentukan dari aspek kualitas sumberdaya manusianya.

Guna meningkatkan kinerja (performance) penyelenggaraan pemerintah desa, maka salah satu tujuan pengaturan desa berdasarkan ketentuan Pasal 4 Undang-Undang Nomor 6 Tahun 2014 tentang Desa adalah membentuk pemerintah desa yang profesional, efisien, efektif, terbuka serta bertanggung jawab. Upaya mewujudkan pemerintahan yang 
profesional ini tidak boleh hanya mengandalkan banyak dukungan dari rakyat, namun hal yang terpenting adalah latar belakang Pendidikan dan pengalaman bagi seorang pemerintah desa. Disamping itu, yang tidak kalah pentingnya adalah aspek moral dan integritas yang menuntut adanya keikhlasan dalam mengembang amanah dan tanggung jawab.

Apabila dikaji secara cermat terhadap upaya untuk mewujudkan pemerintahan desa yang profesional, efisien, efektif, dan bertanggung jawab yang merupakan tujuan pengaturan desa, maka Undang-Undang Nomor 6 Tahun 2014 tentang Desa ini memiliki sisi kelemahan terhadap persyaratan Calon Kepala Desa sebagaimana diatur dalam Pasal 33 Undang-Undang Nomor 6 Tahun 2014 dimana syarat Pendidikan seorang Calon adalah berpendidikan sekurang-kurangnya Sekolah Menengah Tingkat Pertama atau sederajat. Pertanyaan yang muncul kemudian adalah bagaimana mungkin menciptakan seorang pemimpin yang profesional kalua tingkat pendidikannya hanya seorang tamatan Sekolah Tingkat Menengah Pertama atau sederajat, apakah dibangku sekolah setingkat itu sudah pernah diajarkan tentang Ilmu Pemerintahan?, dan kekurangan lainnya adalah dalam ketentuan Pasal 33 Undand-Undang Nomor 6 Tahun 2014 tidak memasukkan pengalaman dibidang Pemerintahan Desa sebagai salah satu persyaratan yang harus dipenuhi bagi seorang Calon Kepala Desa. Padahal, pengalaman itu sangat penting, kata orang bijak "Experience is the best teacher" (Pengalaman adalah guru besar). Oleh Karena itu, orang yang memiliki pengalaman yang baik, lebih berpeluang menjadi orang sukses dalam memimpin daripada orang yang berpendidikan tinggi tapi minim atau tidak punya pengalaman. Namun, alagkah baiknya apabila keduanya dipadukan bagi seorang pemimpin (pemerintah desa). Memiliki kualifikasi Pendidikan yang tinggi dan pengalaman yang banyak ,yang dapat membentuk profesionalitas dalam mengembang tugas dan kewajiban.

Berdasarkan hasil penelitian, para kepala desa di Kecamatan Lantari Jaya, seluruhnya telah memenuhi persyaratan sebagaimana yang diamanatkan dalam ketentuan Pasal 33 Undang-Undang Nomor 6 Tahun 2014, dimana Kepala Desa memiliki Pendidikan terendan adalah Sekolah Lanjut Tingkat Atas (SLTA) atau sederajat, bahkan terdapat dua orang Kepala Desa yang memiliki kualifikasi Pendidikan Sarjana (S1). Hal ini dapat dilihat pada tabel dibawah ini:

Tabel. 1: Data Kualifikasi Pendidikan Formal Kepal Desa Kecamatan Lantari Jaya Tahun 2017

\begin{tabular}{|c|c|c|c|c|c|c|}
\hline No & Desa & Nama Kepala Desa & $\begin{array}{c}\text { Jenis } \\
\text { Kelamin }\end{array}$ & Tempat dan Tanggal Lahir & $\begin{array}{c}\text { Pendidikan } \\
\text { Terakhir }\end{array}$ & Ket \\
\hline
\end{tabular}




\begin{tabular}{|c|l|l|l|l|l|l|}
\hline 1 & Lantari & Ovi Asrofi, S. Sos & Perempuan & Jember, 22-08-1977 & S1 (Ilmu Politik) & - \\
2 & Paser Apua & Abd. Muthalib & Laki-laki & Polmas, 11-05-1971 & SMA & - \\
3 & Anugerah & I. Putu Arbawayasa & Laki-laki & Tuwed, 21-01-1973 & SMA \\
4 & Lombakasih & Abu Bakar & Laki-laki & Kaipute, 09-09-1969 & SMA \\
5 & Langkowala & Juhardi, S.Pd. I & Laki-laki & Lombakasih, 17-07-1985 & S1 (PAI) \\
6 & Rarongkeu & Andi Baso & Laki-laki & Sinjai, 10-12-1990 & SMK & - \\
7 & Kalaero & Ramli & Laki-laki & Sidrap, 04-02-1966 & SMA & - \\
8 & Watu-Watu & Musakkir & Laki-laki & Jayapura, 16-06 1971 & STM & SMA \\
9 & Tinabite & Hasanuddin & Laki-laki & Kendari, 09-03-1973 & SMA & - \\
\hline
\end{tabular}

(Sumber Data: Kantor Camat Lantari Jaya Tahun 2017)

Berdasarkan tabel 1 diatas, dapat diketahui bahwa terdapat dua Kepala Desa dengan kualifikasi Pendidikan Sarjana (S1) yaitu Kepala Desa Lantari dan Kepala Desa Langkowala. Dan tujuh Kepala Desa lainnya kualifikasi Pendidikan Sekolah Menenga Atas (SMA) dan sederajat. Dan dari Sembilan Kepala Desa hanya ada satu perempuan yaitu Kepala Desa Lantari (Ovi Asrofi, S. Sos).

Selanjutnya,hasil penelitian menunjukkan bahwa antara tingkat Pendidikan dan kinerja pemerintah desa memiliki korelasi. Hal ini dapat dilihat dari jawaban responden dari 50 orang, $70 \%$ diantaranya menjawab sudah profesional Kepala Desa dalam menjalankan tugas-tugas pemerintahan desa dan 30\% menjawab kurang profesional. Data selengkapnya dapat dilihat pada tabel berikut ini:

Tabel 2: Data Pendapat Responden Terhadap Pelaksanaan Tugas-Tugas Pemerintahan Desa Dikecamatan Lantari Jaya Tahun 2017

\begin{tabular}{|c|c|c|c|}
\hline NO & INDIKATOR & FREKWENSI & PERSENTASE (\%) \\
\hline 1 & Sudah professional & 35 & 70 \\
\hline 2 & Kurang Profesional & 15 & 30 \\
\hline 3 & Tidak Profesional & 0 & 0 \\
\hline 4 & Tidak Tahu & 0 & 0 \\
\hline & JUMLAH & 50 & 100 \\
\hline
\end{tabular}

(Sumber Data: Diolah dari Jawaban Responden Tahun 2017)

2. Faktor Sumberdaya Alam

Kecamatan Lantari Jaya sebagai bagian dari wilayah Kabupaten Bombana memiliki sumber kekayaan alam (natural resource) yang cukup strategis bagi aktifitas pembangunan masyarakat, terutama dari sektor pertanian, perkebunan, peternakan, perikanan dan 
pertambangan. Oleh Karena itu, tantangan yang harus dihadapi oleh pemerintah desa adalah bagaimana mengelola sumberdaya ala mini agar bias mendatangkan berkah, membawa kemakmuran dan kesejahteraan masyarakat melalui penerapan prinsip-prinsip manajemen strategik. Karena pada prinsipnya tidak ada di Dunia ini negara atau daerah yang miskin, yang ada hanya negara yang salah kelolah, demikian pernyataan guru manajemen sejagat Peter Drucker yang menyatakan bahwa "There are no under developed countries, only under managed ones".

Dalam konteks peningkatan kinerja (Performance) pemerintah desa sebagai garda terdepan dalam pembangunan. Sumberdaya alam memiliki pengaruh yang sangat penting terhadap keberhasilan pelaksanaan tugas dan kewajiban pemerintah terutama dilihat dari aspek pendekatan pembangunan (development approach). Hal ini dapat dilihat dari pendapat responden sebagaimana diuraikan pada tabel dibawah ini:

Tabel 3: Data Pengaruh Sumber Daya Alam Terhadap Kinerja Pemerintah Desa Di Kecamatan Lantari Jaya Tahun 2017

\begin{tabular}{|c|l|c|c|}
\hline NO & \multicolumn{1}{|c|}{ INDIKATOR } & FREKUENSI & PRESENTASE (\%) \\
\hline 1 & Sangat berpengaruh & 23 & 46 \\
2 & Berpengaruh & 26 & 52 \\
3 & Kurang berpengaruh & 1 & 2 \\
4 & Tidak berpengaruh & 0 & 0 \\
\hline & JUMLAH & 50 & 100 \\
\hline
\end{tabular}

(Sumber Data: Diolah dari Jawaban Responden Tahun 2017)

Berdasarkan uraian pada Tabel 3 diatas, dapat diketahui bahwa jawaban responden tertinggi terhadap pengaruh sumberdaya alam terhadap peningkatan kinerja pemerintah desa adalan berpengaruh, yaitu sebanyak 26 responden atau 52\%. Hal ini menunjukkan bahwa upaya yang harus dilakukan pemerintah desa untuk meningkatkan perekonomian dan kesejahteraan masyarakat adalah mengoptimaliasasi pengelolaan sumberdaya alam melalui pola manajemen yang profesional yang didukung oleh penerapan teknologi tepat guna yang berbasis agro industri sesuai dengan karakteristik masyarakat pedesaan sebagai masyarakat agraris.

3. Faktor Peralatan atau Sarana Prasarana

Betapapun tingginya kualitas sumberdaya manusia yang dimiliki suatu organisasi dalam menjalankan peran dan fungsinya tanpa dukungan peralatan atau sarana-prasarana yang memadai, tetap menyisahkan suatu masalah, mengingat diabad modern ini menuntut adanya pelayanan yang prima. Kualitas pelayanan yang baik dan ketepatan waktu selalu 
dijadikan parameter kinerja setiap Instansi Pemerintahan tidak terkecuali pemerintah desa yang lansung berinteraksi dengan warga masyarakat.

Berdasarkan hasil penelitian, penulis dan pendapat responden yang berkaitan dengan kelengkapan peralatan dan sarana-prasarana pemerintahan desa di Kecamatan Lantari Jaya, menunjukkan bahwa peralatan atau sarana-prasarana yang ada sekarang belum memadai atau masih kurang, walaupun sebahagian besar pengapat responden mengatakan sudah lengkap. Hal ini dapat dilihat pada tabel dibawah ini:

Tabel 4: Kondisi Peralatan Dan Sarana Prasarana Pemerintah Desa Di Kecamatan Lantari Jaya Tahun 2017

\begin{tabular}{|c|l|c|c|}
\hline NO & \multicolumn{1}{|c|}{ INDIKATOR } & FREKuENSI & PERSENTASE (\%) \\
\hline 1 & Sudah Lengkap & 26 & 52 \\
2 & Kurang Lengkap & 22 & 44 \\
3 & Tidak Lengkap & 2 & 6 \\
4 & Tidak Ada & 0 & 0 \\
\hline & \multicolumn{1}{|c|}{ JUMLAH } & 50 & 100 \\
\hline
\end{tabular}

(SumberData: Diolah dari Jawaban Responden Tahun 2017)

Berdasarkan uraian Tabel 4 di atas, menunjukkan bahwa kondisi peralatan atau sarana-parasarana pemerintah desa, pendapat yang paling banyak menyatakan sudah lengkap yaitu 26 (52\%) responden, dan pendapat paling rendah/ kurang persentasenya adalah pendapat yang menyatakan tidak lengkap yaitu $2(6 \%)$ responden.

4. Faktor Motivasi

Motivasi atau motif berasal dari Bahasa latin dari kata "motivasi" yang memiliki tiga pengertian penting, yaitu: (a) gambaran penyebab yang akan menimbulkan tingkah laku menuju sasaran tertentu, (b) alasan dasar, pikiran dasar, dan dorongan bagi seseorang untuk berbuat, dan (c) Ide pokok yang sementara berpengaruh besar terhadap tingkah laku manusia, biasanya merupakan suatu peristiwa masa lampau, ingatan, gambaran fantasi dan perasaan tertentu.

Selain pengertian diatas, Barelson Steiner dalam Kartini Kartono (1998: 92) mendefinisikan motivasi sebagai berikut "A motive is an inner state that energizes or moves (hence motivation) and that direct or channels behavior towards goal" (suatu motif adalah suatu keadaan batiniah yang memberikan energi kepada aktivitas-aktivitas atau 
menggerakkannya, Karena itu motivasi mengarahkan atau menyalurkan tingkah laku pada suatu tujuan).

Definisi motivasi di atas, memberikan panduan bagi seorang pemimpin (pemerintah desa) untuk senantiasa membangun motivasi, baik pada diri sendiri maupun pada orang lain sebagai sumber inspirasi untuk melakukan yang terbaik bagi kepentingan organisasi untuk mencapai tujuan. Motivasi adalah kekuatan yang maha dahsyat untuk mempersembahkan pengabdian yang terbaik, bagi kepentingan bangsa dan negara, dan motivasi melebihi nilainya dari sebuah kekayaan (kapital) dalam meraih sebuah keberhasilan sebagaimana ungkapan bijak pakar manajemen Peter Drucker dalam Mr. Mustamin DG Matut (2004: 34) mengatakan bahwa "Capital without labour is sterile, but well motivated labour without capital can move mountain" (Modal tanpa tenaga kerja adalah mandul, tapi tenaga kerja termotivasi baik dapat memindahkan gunung tanpa modal).

Berdasarkan uraian di atas, maka yang menjadi kata kunci dalam meraih keberhasilan dalam kepemimpinan organisasi pemerintahan adalah motivasi, dan dengan motivasi setiap orang bersedia dan rela melakukan perbuatan -perbuatan besar atau perbuatan kepahlawanan lainnya untuk meraih keberhasilan dalam penyelenggaraan pemerintah desa. Hal ini dapat dilihat pada tabel berikut tentang pengaruh motivasi terhadap keberhasilan penyelenggaraan pemerintah desa.

Tabel 5: Data Pengaruh Motivasi Terhadap Keberhasilan Penyelenggaraan Pemerintah Desa Di Kecamatan Lantari Jaya

\begin{tabular}{|c|l|c|c|}
\hline NO & \multicolumn{1}{|c|}{ INDIKATOR } & FREKUENSI & PERSENTASE (\%) \\
\hline 1 & Sangat berpengaruh & 32 & 64 \\
2 & Berpengaruh & 12 & 24 \\
3 & Tidak Berpengaruh & 6 & 16 \\
\hline \multicolumn{2}{|c|}{ Jumlah } & 50 & 100 \\
\hline
\end{tabular}

(Sumber Data: Diolah dari jawaban Responden Tahun 2017)

Dari uraian tabel 5 di atas, dapat diketahui bahwa pengaruh motivasi terhadap peningkatan kinerja pemerintahan desadalam pelaksanaan tugas-tugas pemerintahan, pembangunan dan pelayanan masyarakat sangat signifikan, dimana 32 responden $(64 \%)$ menjawab sangat berpengaruh.

Selain ke empat faktor di atas, faktor yang lain yang memegang peranan penting dalam politik pemberdayaan pemerintah desa untuk mewujudkan kesejahteraan masyarakat 
(Social welfare), adalah kebijaksanaan dari pemerintah supra desa yang merupakan dukungan politik (political will) dalam penguatan otonomi desa, mengingat keberadaan desa sebagai subyek pembangunan yang berada pada garda terdepan di negara republik ini.

Kebijaksanaan pemerintah (public policy) dalam pandangan James E. Anderson dalam bukunya "Public Policy Making" (1984: 2) berbunyi Public policy is relationship of a government unit to it's emvironment (Kebijaksanaan adalah hubungan suatu lembaga pemerintah terhdap lingkungannya) definisi ini mempunyai arti yang sangat luas, namun yang terpenting adalah bagaimana membangun komunikasi dan kerja sama dengan berbagai elemen dalam lingkungan organisasi untuk mencapai tujuan.

Kebijaksanaan pemerintah dalam pengaturan pemerintahan desa dituangkan dalam berbagai bentuk peraturan Perundang-Undangan sejak berdirinya Negara Republik ini yang diproklamasikan pada Tanggal 17 Agustus 1945. Namun, belum sepenuhnya memenuhi tuntutan kebutuhan masyarakat dalam mewujudkan kesejahteraan. Hal ini menjadi problematika dalam dinamika politik pemerintahan dalam era globalisasi dan modernisasi sekarang ini.

Ketika reformasi menemukan momentum untuk melakukan perubahan di tahun 1998, Orde Baru jatuh digantikan Orde Reformasi. Eksistensi desa dan kesatuan masyarakat hukum adat kembali mendapatkan pengakuan, tetapi sayang eksistensi desa dan kesatuan masyarakat hukum adat direduksi menjadi bagian dari wilayah atau daerah Kabupaten/ Kota yang pengaturannya disatukan dalam UU. No. 22 Tahun 1999 tentang Pemerintahan Daerah. Dalam perspektif politik hukum, lahirnya UU. No. 6 Tahun 2014 tentang Desa adalah buah pergulatan politik panjang, sekaligus pergulatan pemikiran untuk menjadikan desa sebagai basis pembangunan kualitas kehidupan. Selain itu, pelaksanaan pengaturan desa melalui peraturan Perundang-Undangan sebelumnya sudah tidak sesuai lagi dengan perkembangan zaman, terutama menyangkut kedudukan masyarakat hukum adat, demokratisasi, keberagaman, partisipasi masyarakat, serta kemajuan dan pemerataan pembangunan, sehingga menimbulkan kesenjangan antar wilayah, kemiskinan, dan masalah sosial budaya yang dapat mengganggu keutuhan Negara Kesatuan Republik Indonesia. 
Undang-Undang Nomor 6 Tahun 2014 tentang Desa terdiri atas 16 bab dan 122 pasal, memuat kebijakan-kebijakan strategis bagi kemajuan dan perkembangan desa. Undang-Undang ini juga menghargai eksistensi desa dan peranan aparatur desa, dan secara tegas memberikan ancaman pemberian sangsi kepada Kepala Desa yang tidak menjalankan kewajibannya. Sanksinya bisa teguran tertulis, pemberhentian sementara dan pemberhentian tetap. Hal ini berimplikasi positif dalam mendorong kinerja dan disiplin pemerintah desa.

Dalam pandangan Didik Sukriono (2014: 27), UU. No. 6 Tahun 2014 tentang Desa dikatakan sebagai Undang-Undang Desa terlengkap dibanding Undand-Undang Desa sebelumnya. Namun, oleh sebahagian pengamat berpendapat bahwa UU. Desa ini masih terdapat beberapa kelemahan, antara lain: (a) Pengertian tentang desa adat yang berbeda dengan pengertian masyarakat desa adat itu sendiri. Perbedaan ini berpotensi menimbulkan dampak di kemudian hari jika tidak ditanggulangi sejak dini; (b) Dana alokasi yang berasal dari APBN dan tergolong cukup besar terhadap setiap desa pertahunnya, juga bisa menjadi permasalahan jika tidak diawasi secara maksimal dan berkala; (c) Tidak adanya pembahasan secara khusus pada UU Desa tentang Penempatan Perempuan minimal 30\% pada perangkat desa; (d) Belum siapnya sumberdaya manusia (SDM) yang ada di desa untuk menjalankan UU Desa ini, dan tentunya akan berdampak terhadap tata kelola pemerintahan desa itu sendiri.

Lahirnya UU. No. 6 Tahun 2014 tentang Desa, merupakan produk politik hukum yang bertujuan untuk mewujudkan kemakmuran dan kesejahteraan masyarakat, jika tidak dikawal dengan baik melalui penegakan (enforcement) maka masyarakat desa berpotensi menjadi second society sepanjang sejarah. Padahal, dalam khasanah klasik Ibnu Khaldun (1332 - 1406) dalam kosep ashabiyah (kesukuan) -nya mengatakan bahwa sesungguhnya manusia atau masyarakat itu dimulai dari masyarakat desa.

Dilihat dari optik sosiologis, implementasi UU. No. 6 Tahun 2014 tentang Desa di Kecamatan Lantari Jaya Kabupaten Bombana menurut pendapat responden, sebagian besar menjawab bahwa UU Desa ini sudah efektif pelaksanaannya. Hal ini dapat dilihat pada uraian tabel jawaban responden di bawah ini: 
Tabel 6: Data Tingkat Efektifitas Implementasi Uu No 6 Tahun 2014 Tentang Desa Di Kecamatan Lantari Jaya Tahun 2017.

\begin{tabular}{|c|l|c|c|}
\hline NO & \multicolumn{1}{|c|}{ INDAKATOR } & FREKWENSI & PERSENTASE \\
\hline 1 & Sangat Efektif & 21 & 32 \\
2 & Efektif & 38 & 66 \\
3 & Kurang efektif & - & 0 \\
4 & Tidak efektif & 1 & 2 \\
\hline \multicolumn{2}{|c|}{ JUMLAH } & 50 & 100 \\
\hline
\end{tabular}

(Sumber Data: Diolah dari hasil Jawaban Responden Tahun 2017)

Berdasarkan uraian tabel 6 di atas, dapat diketahui bahwa jawaban responden menyatakan efektif berlaku UU. No. 6 Tahun 2014 tentang Desa sebagai jawaban tertinggi yaitu sebanyak 38 atau 66\% jawaban ini didasarkan pada indikator tentang penyelenggaraan pemerintahan, pembangunan dan kemasyarakatan.

\section{KESIMPULAN}

Kesimpulan

Politik hukum pemberdayaan pemerintah desa bertujuan untuk meningkatkan kemandirian desa dalam mengatur dan mengurus rumah tangganya sendiri, tanpa bergantung dari pihak luar. Namun dalam upaya untuk meraih keberhasilan dalam pembangunan masyarakat guna mewujudkan kesejahteraan (social welfare) dipengaruhi oleh beberapa faktor antara lain: faktor sumberdaya manusia, sumberdaya alam, peralatan atau sarana dan prasarana, serta motivasi. Disamping itu, memerlukan dukungan politik (political will) dari pemerintah dalam bentuk formulasi kebijakan atau regulasi dalam mengatur pemberdayaan pemerintah desa.

Saran

Dalam rangka penguatan pelaksanaan pemberdayaan pemerintah desa serta pembentukan pemerintahan desa yang profesional, efektif, efisien dan bertanggung jawab sesuai amanat Undang-Undang Nomor 6 Tahun 2014 tentang Desa, maka Pemerintah Daerah Kabupaten Bombana hendaknya membentuk Peraturan Daerah tentang pemberdayaan pemerintah desa guna meningkatkan kinerja pembangunan dalam mewujudkan kesejahteraan masyarakat (social welfare). 


\section{DAFTAR PUSTAKA}

Abdurrauf Tarimana, 1993, Kebudayaan Tolaki, Balai Pustaka, Jakarta.

Didik Sukriono, 2014, Undang-Undang Desa dan Permasalahan Sosial Budaya, In-Trans Institute: Malang.

Hanif Nurcholis, 2011, Pertumbuhan dan Penyelenggaraan Pemerintahan Desa, Erlangga: Jakarta.

Kartini Kartono, 1998, pemimpin dan kepemimpinan, PT. Raja Grafindo Persada: Jakarta.

Koentjaraningrat, 1984, Masyarakat Desa di Indonesia, LPEE-UI: Jakarta.

La Ode Husen, 2009, Negara Hukum, Demokrasi Dan Pemisahan Kekuasaan, PT.

Umitoha Ukhuwa Grafika: Makassar.

Mustaming DG. Matutu, et.al. 1999, Mandat, Delegasi, Attribusi dan Implementasinya di Indonesia, UII Press, Yogyakarta.

Ni'matul Huda, 2015, Hukum Pemerintahan Desa Dalam Konstitusi Indonesia, Sejak Kemerdekaan Hingga Era Reformasi, Setara Press: Malang.

Nurul Qamar, 2012, Pengantar Politik Hukum Ketatanegaraan, Pustaka Refleksi

Makassar.

Rahardjo Adisasmita, dkk,2007, Pembangunan Desa Partisipatif, Desa Pusat

Pertumbuhan dan Desa Mandiri, toACCAe, Makassar.

Sutoro Eko., 2005. Masa Lalu, Masa Kini dan Masa Depan Otonomi Desa, Yayasan Tifa, Jakarta.

Umbu Pariangu, 2014, Memoles Wajah Kapasitas dan Integritas Aparatur Desa dalam Bingkai Undang-Undang Desa, In-Trans Institut: Malang 